\title{
Genome-wide association study of leaf rust resistance in Russian spring wheat varieties
}

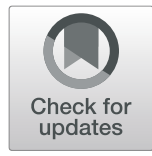

\author{
Irina N. Leonova ${ }^{1 *}$, Ekaterina S. Skolotneva ${ }^{1}$ and Elena A. Salina ${ }^{2}$ \\ From Fifth International Scientific Conference "Plant Genetics, Genomics, Bioinformatics, and Biotechnology" (PlantGen2019) \\ Novosibirsk, Russia. 24-29 June 2019
}

\begin{abstract}
Background: Leaf rust (Puccinia triticina Eriks.) is one of the most dangerous diseases of common wheat worldwide. Three approaches: genome-wide association study (GWAS), marker-assisted selection (MAS) and phytopathological evaluation in field, were used for assessment of the genetic diversity of Russian spring wheat varieties on leaf rust resistance loci and for identification of associated molecular markers.

Results: The collection, consisting of 100 Russian varieties of spring wheat, was evaluated over three seasons for resistance to the native population of leaf rust specific to the West Siberian region of Russia. The results indicated that most cultivars showed high susceptibility to $P$. triticina, with severity ratings (SR) of 60S-90S, however some cultivars showed a high level of leaf rust resistance (SR < 20MR-R). Based on the results of genome-wide association studies (GWAS) performed using the wheat $15 \mathrm{~K}$ genotyping array, 20 SNPs located on chromosomes 6D, 6A, 6B, $5 \mathrm{~A}, 1 \mathrm{~B}, 2 \mathrm{~A}, 2 \mathrm{~B}$ and $7 \mathrm{~A}$ were revealed to be associated with leaf rust resistance. Genotyping with markers developed for known leaf rust resistance genes showed that most of the varieties contain genes $\operatorname{Lr} 1, \operatorname{Lr} 3 a, \operatorname{Lr}$, Lr10, Lr17a, Lr20, Lr26 and Lr34, which are not currently effective against the pathogen. In the genome of three wheat varieties, gene $L r 6 A i=2$ inherited from Th. intermedium was detected, which provides complete protection against the rust pathogen. It has been suggested that the QTL mapped to the chromosome 5AS of wheat cultivar Tulaikovskayazolotistaya, Tulaikovskaya-10, Samsar, and Volgouralskaya may be a new, previously undescribed locus conferring resistance to leaf rust. Obtained results also indicate that chromosome 1BL of the varieties Sonata, Otrada-Sibiri, Tertsiya, Omskaya-23, Tulaikovskaya-1, Obskaya-14, and Sirena may contain an unknown locus that provides a resistance response to local population.
\end{abstract}

Conclusions: This study provides new insights into the genetic basis of resistance to leaf rust in Russian spring wheat varieties. The SNPs significantly associated with leaf rust resistance can be used for the development and application of diagnostic markers in marker-assisted selection schemes.

Keywords: Common wheat, Leaf rust, Puccinia triticina, GWAS, Lr genes

\footnotetext{
*Correspondence: leonova@bionet.nsc.ru

${ }^{1}$ The Federal Research Center Institute of Cytology and Genetics of Siberian Branch of the Russian Academy of Sciences, Novosibirsk 630090, Russia

Full list of author information is available at the end of the article
}

(c) The Author(s). 2020, corrected publication 2020. Open Access This article is licensed under a Creative Commons Attribution 4.0 International License, which permits use, sharing, adaptation, distribution and reproduction in any medium or format, as long as you give appropriate credit to the original author(s) and the source, provide a link to the Creative Commons licence, and indicate if changes were made. The images or other third party material in this article are included in the article's Creative Commons licence, unless indicated otherwise in a credit line to the material. If material is not included in the article's Creative Commons licence and your intended use is not permitted by statutory regulation or exceeds the permitted use, you will need to obtain permission directly from the copyright holder. To view a copy of this licence, visit http://creativecommons.org/ licenses/by/4.0/. The Creative Commons Public Domain Dedication waiver (http://creativecommons.org/publicdomain/zero/1. 0/) applies to the data made available in this article, unless otherwise stated in a credit line to the data. 


\section{Background}

Bread wheat (T. aestivum L.) is one of the most valuable food and feed crops and one of the main sources of dietary protein and carbohydrates. The Russian Federation, along with China, India and the United States, is one of the world's largest producers and exporters of bread wheat. The main characteristics of modern varieties include high grain yield and quality, adaptability to environmental factors and resistance to diseases and insects.

Among the diseases causing significant yield losses in bread wheat, leaf rust (Puccinia triticina Eriks.) is the most widespread and dangerous one. In Russia, this disease occurs annually in all regions of winter and spring wheat cultivation, and accounts for crop losses of $40 \%$ or more [1, 2]. Significant damage from leaf rust occurs in the Volga, Central, North Caucasus and Ural regions. According to long-term studies, the severity of leaf rust in Western Siberia has also increased drastically over the past 20 years [3]. Since the early 2000s, the epiphytoties of leaf rust were observed in 2000, 2001, 2005, 2007, 2008, 2010 and 2011. The main factors, in addition to weather conditions, contributing to this process, include the changed virulence and aggressiveness of the pathogen population, combined with the high susceptibility of wheat varieties. Consequently, in recent years much attention has been paid to the creation of varieties with a genetic basis for leaf rust resistance, to prevent crop losses and reduce the pesticide load on the environment.

To date, more than $100 \mathrm{Lr}$ (leaf rust) genes with permanent and temporary symbols controlling seedling and adult plant resistance to leaf rust have been described in wheat. Of these, more than half were inherited from the genomes of wild and cultivated wheat relatives: Secale cereale, Ae. tauschii, Ae. speltoides, T. timopheevii, Th. elongatum, Th. intermedium, T. dicoccoides, Ae. ventri$\cos a$, etc. [4]. Different approaches are used to postulate the presence of $\mathrm{Lr}$ genes in wheat cultivars and breeding lines. The conventional method includes phytopathological screening in response to inoculation of plants by pathogen isolates, with further comparison to the resistance/susceptibility reactions of a set of isogenic lines and wheat cultivars containing known $\operatorname{Lr}$ genes. This method is used to infer the presence in the genome of single genes and previously unknown resistance factors [5-7].

Another, more modern approach involves the application of DNA markers (SSRs, STS, SCAR, CAPS) developed for known leaf rust resistance genes [8, 9]. However, despite the fact that molecular markers are available for almost all $L r$ genes, only a small number of them are diagnostic and recommended for use in marker-assisted selection (http://maswheat.usdavis.edu/ protocols). Most of the markers were developed using mapping populations derived from bi-parental crosses, which is one of the reasons for the decrease or complete absence of their specificity in the detection of $\mathrm{Lr}$ genes in another genetic background [10-12].

The most modern methodological approach, based on the application of a large number of SNP markers and the principles of linkage disequilibrium (LD), is the genome wide association study (GWAS). Currently, GWAS is widely used to identify the genetic factors that determine various agronomically important characteristics of agricultural plants, including resistance to fungal diseases, the duration of the vegetative period, grain yield and quality [13-16]. GWAS allows us to determine the presence of both known resistance genes and previously unidentified loci [17, 18]. For example, using this approach, a collection of 338 cultivated varieties of spring soft wheat was studied, and 46 QTLs responsible for resistance to leaf rust at seedling and adult plant stages were detected [19]. In another study, potentially new $\mathrm{Lr}$ loci were identified in the genome of spring bread wheat using a panel consisting of 1032 varieties [20].

Data on the genetic resistance of varieties created in the USSR and varieties of modern selection are practically absent, and what little exists is not systematized and is often only weakly indicative. There are few examples of published results, which suggest that released varieties from selections of the USSR contain ineffective genes Lr3, Lr10, Lr13 [21-24]. Based on the results of molecular marker analysis of modern Russian varieties from the Volga region and Krasnodar breeding, it was assumed that they probably contain genes $\operatorname{Lr} 9, \operatorname{Lr} 19, \operatorname{Lr} 26$, as well as unknown genes from Agropyron ssp. [25, 26].

Information on the level of resistance of modern wheat varieties and genetic basis of resistance is needed to expand the pool of resistant cultivars available for breeding. The aim of this study was: 1) to assess the level of susceptibility of Russian spring wheat varieties to the natural population of leaf rust; and 2) to postulate the presence of $\mathrm{Lr}$ genes based on the results of GWAS and molecular marker analysis specific to known $L r$ genes.

\section{Results}

\section{Field resistance of wheat varieties to leaf rust}

Weather conditions in the West Siberian region in 2016-2018 favored the development of plant infection with the leaf rust pathogen (Additional file 1: Table S1). The growing season of 2018 was characterized by lower temperatures in May and significant overmoistening in May - June comparing with 2016-2017. The first symptoms of the rust infection in 2018 appeared a week later than in other years. A field evaluation of the resistance of 100 wheat varieties to the natural population of leaf rust specific to the West Siberian region showed that 38 cultivars displayed high susceptibility (IT $=4,60-90 \%$ on the Cobb's scale) on both experimental fields over three 
Table 1 List of spring wheat varieties, their origin, leaf rust severity and postulated $L r$ resistance genes

\begin{tabular}{|c|c|c|c|c|c|c|c|c|}
\hline \multirow[t]{2}{*}{ Variety } & \multirow[t]{2}{*}{ Region/Originator } & \multirow[t]{2}{*}{ Cluster $^{\mathrm{a}}$} & \multicolumn{5}{|c|}{ Infection type/severity ${ }^{b}$} & \multirow{2}{*}{$\begin{array}{l}\text { Postulated } L r \\
\text { genes }\end{array}$} \\
\hline & & & $\begin{array}{l}\text { Field-1- } \\
2016\end{array}$ & $\begin{array}{l}\text { Field-1- } \\
2017\end{array}$ & $\begin{array}{l}\text { Field-1- } \\
2018\end{array}$ & $\begin{array}{l}\text { Field-2- } \\
2016\end{array}$ & $\begin{array}{l}\text { Field-2- } \\
2017\end{array}$ & \\
\hline Kuibyshevskaya-2 & \multirow[t]{11}{*}{ Samarskaya Oblast / Samarskii NIISKH } & V & $4 / 90 S$ & $4 / 905$ & $4 / 70 S$ & $4 / 60 \mathrm{~S}$ & $4 / 80 S$ & Lr34 \\
\hline Lutescens-840 & & । & $4 / 70 S$ & $4 / 40 S$ & $4 / 70 \mathrm{~S}$ & $4 / 60 \mathrm{~S}$ & $4 / 605$ & Lr10 \\
\hline Samsar & & IV & $0 / R$ & $0 / R$ & $0 / R$ & $0 / R$ & $0 / R$ & $\begin{array}{l}\operatorname{Lr} 3 a, \operatorname{Lr} 17 a, L r 20, \\
\operatorname{Lr} 6 A i=2\end{array}$ \\
\hline $\begin{array}{l}\text { Tulaikovskaya- } \\
\text { belozernaya }\end{array}$ & & । & $4 / 70 S$ & $4 / 905$ & 3/40MS & $4 / 30 \mathrm{~S}$ & $4 / 30 S$ & Lr3a \\
\hline $\begin{array}{l}\text { Tulaikovskaya- } \\
\text { stepnaya }\end{array}$ & & । & $4 / 50 \mathrm{~S}$ & $4 / 50 \mathrm{~S}$ & $3 / 20 M S$ & $4 / 30 S$ & $4 / 30 S$ & Lr3a, Lr10, Lr17a \\
\hline $\begin{array}{l}\text { Tulaikovskaya- } \\
\text { zolotistaya }\end{array}$ & & IV & $0 / R$ & $0 / R$ & $0 / R$ & $0 / R$ & $0 / R$ & $\operatorname{Lr} 3 a, \operatorname{Lr} 6 A i=2$ \\
\hline Tulaikovskaya-1 & & IV & 2/15MR & $0 / R$ & 2/30MR & $0 / R$ & $0 / R$ & $\operatorname{Lr} 3 a, \operatorname{Lr} 17 a$ \\
\hline Tulaikovskaya-10 & & IV & $0 / R$ & $\mathrm{OR}$ & $0 / R$ & $0 / R$ & $0 / R$ & $\operatorname{Lr} 3 a, \operatorname{Lr} 20, \operatorname{Lr} 6 A i=2$ \\
\hline Kinelskaya-40 & & IV & $4 / 805$ & $4 / 80 S$ & 3/40MS & $4 / 40 S$ & $4 / 605$ & Lrro \\
\hline Kinelskaya-60 & & 1 & 2/20MR & 3/20MS & 2/15MR & $3 / 10 \mathrm{MS}$ & 3/20MS & $\operatorname{Lr} 17 a, \operatorname{Lr} 26$ \\
\hline Volgouralskaya & & IV & $0 / R$ & $1 / 5 \mathrm{MR}$ & $1 / 5 \mathrm{MR}$ & $0 / R$ & $1 / 5 \mathrm{MR}$ & $\operatorname{Lr} 19$ \\
\hline Saratovskaya-29 & \multirow{3}{*}{$\begin{array}{l}\text { Saratovskaya Oblast / NIISKH Yugo- } \\
\text { Vostoka }\end{array}$} & IV & $4 / 905$ & $4 / 905$ & $4 / 70 \mathrm{~S}$ & $4 / 70 \mathrm{~S}$ & $4 / 70 S$ & $\operatorname{Lr} 3 a, \operatorname{Lr} 10$ \\
\hline Saratovskaya-42 & & IV & $4 / 805$ & $4 / 805$ & $4 / 805$ & - & $4 / 70 S$ & $\operatorname{Lr} 3 a$ \\
\hline Lutescens-62 & & IV & $4 / 70 \mathrm{~S}$ & $4 / 80 S$ & $4 / 805$ & - & $4 / 70 S$ & $\angle r 3 a$ \\
\hline Lutescens-80 & \multirow[t]{10}{*}{ Altaiskii Krai / Altaiskii NIIZIS } & III & $4 / 605$ & $4 / 805$ & $4 / 80 \mathrm{~S}$ & $4 / 60 \mathrm{~S}$ & $4 / 60 \mathrm{~S}$ & $\operatorname{Lr} 3 a, \operatorname{Lr} 10$ \\
\hline Lutescens-85 & & IV & $3 / 60 M S$ & 3/50MS & 3/30MS & $3 / 20 M S$ & 3/40MS & $L r 1, L r 3 a, \operatorname{Lr} 7 a$ \\
\hline Lutescens-148 & & III & $4 / 805$ & $4 / 605$ & $4 / 605$ & $4 / 70 S$ & $4 / 905$ & Lr3a, Lr10, Lr20 \\
\hline Altaiskii-prostor & & III & $4 / 605$ & $4 / 70 S$ & $4 / 70 \mathrm{~S}$ & $4 / 205$ & $4 / 50 \mathrm{~S}$ & $\begin{array}{l}\operatorname{Lrg}, \operatorname{Lr} 10, \operatorname{Lr} 17 a \\
\operatorname{Lr} 20\end{array}$ \\
\hline Altaiskaya-92 & & V & $4 / 705$ & $4 / 805$ & $4 / 805$ & $4 / 10 S$ & $4 / 40 S$ & Lr3a, Lr17a, Lr34 \\
\hline Altaiskaya-99 & & V & 3/10MS & 3/30MS & 3/15MS & $3 / 20 M S$ & 3/20MS & Lr3a, Lr9 \\
\hline Altaiskaya-100 & & IV & 3/40MS & 3/60MS & 3/40MS & $3 / 10 \mathrm{MS}$ & 3/10MS & Lr1, Lr3a \\
\hline Altaiskaya-325 & & V & $4 / 805$ & $4 / 905$ & $4 / 60 \mathrm{~S}$ & $4 / 70 \mathrm{~S}$ & $4 / 905$ & $\begin{array}{l}\operatorname{Lr} 3 a, \operatorname{Lr} 10, \operatorname{Lr} 17 a \\
\operatorname{Lr} 20\end{array}$ \\
\hline Altaiskaya-530 & & V & $4 / 605$ & $4 / 70 S$ & $4 / 70 S$ & $4 / 40 S$ & $4 / 50 S$ & Lr1, Lr3a \\
\hline Erythrospermum-72 & & $\|$ & $4 / 605$ & $4 / 80 S$ & 3/50MS & $4 / 70 S$ & $4 / 905$ & $\operatorname{Lr} 1$ \\
\hline Sibirskaya-12 & \multirow[t]{15}{*}{ Novosibirskaya Oblast / SibNIIRS } & 1 & $4 / 80 \mathrm{~S}$ & $4 / 80 \mathrm{~S}$ & $4 / 50 \mathrm{~S}$ & $4 / 50 \mathrm{~S}$ & $4 / 605$ & Lr3a, Lr10 \\
\hline Novosibirskaya-15 & & III & $4 / 805$ & $4 / 905$ & $4 / 80 S$ & $4 / 60 S$ & $4 / 70 S$ & Lr1, Lr3a, Lr10 \\
\hline Novosibirskaya-20 & & III & $4 / 70 S$ & $4 / 905$ & $4 / 80 \mathrm{~S}$ & $3 / 30 M S$ & 3/40MS & Lr3a, Lr10 \\
\hline Novosibirskaya-22 & & III & $4 / 805$ & $4 / 70 \mathrm{~S}$ & $4 / 60 \mathrm{~S}$ & $4 / 605$ & $4 / 70 \mathrm{~S}$ & Lr3a, Lr10 \\
\hline Novosibirskaya-29 & & V & $4 / 905$ & $4 / 905$ & $4 / 80 \mathrm{~S}$ & $4 / 70 S$ & $4 / 70 \mathrm{~S}$ & Lr3a, Lr10 \\
\hline Novosibirskaya-67 & & V & $4 / 90 S$ & $4 / 905$ & $4 / 805$ & $4 / 80 S$ & $4 / 90 S$ & $L r 17 a$ \\
\hline Novosibirskaya-81 & & 1 & $4 / 70 S$ & $4 / 905$ & $4 / 70 S$ & $4 / 605$ & $4 / 605$ & Lr1, Lrr7a, Lr20 \\
\hline Novosibirskaya-89 & & V & $4 / 70 S$ & $4 / 905$ & $4 / 605$ & $4 / 90 S$ & $4 / 90 S$ & $\operatorname{Lr} 10, \operatorname{Lr} 20$ \\
\hline Novosibirskaya-91 & & IV & $4 / 605$ & $4 / 70 S$ & $4 / 70 S$ & $4 / 605$ & $4 / 605$ & Lr1 \\
\hline Lutescens-25 & & III & $4 / 70 S$ & $4 / 90 S$ & $4 / 70 S$ & $4 / 50 \mathrm{~S}$ & $4 / 70 S$ & Lr3a, Lr10 \\
\hline Obskaya-14 & & V & 2/40MR & 2/20MR & $1 / 5 \mathrm{MR}$ & $0 / R$ & $0 / R$ & Lr3a, Lrg, Lr10 \\
\hline Kantegirskaya-89 & & V & $4 / 605$ & $4 / 805$ & $4 / 805$ & $4 / 15 S$ & $4 / 15 S$ & Lr3a, Lr10 \\
\hline Aleksandrina & & V & $3 / 25 \mathrm{MS}$ & 3/30MS & $4 / 50 S$ & $4 / 50 S$ & $4 / 40 S$ & Lr3a, Lrg \\
\hline Udacha & & V & $3 / 25 \mathrm{MS}$ & $4 / 805$ & 3/40MS & $4 / 10 S$ & $4 / 50 S$ & Lr3a, Lrg, Lr20 \\
\hline Polushko & & III & $4 / 605$ & $4 / 80 S$ & $4 / 70 \mathrm{~S}$ & $4 / 70 \mathrm{~S}$ & $4 / 805$ & Lr1, Lr3a, Lr10 \\
\hline
\end{tabular}


Table 1 List of spring wheat varieties, their origin, leaf rust severity and postulated $L r$ resistance genes (Continued)

\begin{tabular}{|c|c|c|c|c|c|c|c|c|}
\hline \multirow[t]{2}{*}{ Variety } & \multirow[t]{2}{*}{ Region/Originator } & \multirow[t]{2}{*}{ Cluster $^{a}$} & \multicolumn{5}{|c|}{ Infection type/severity ${ }^{b}$} & \multirow{2}{*}{$\begin{array}{l}\text { Postulated } L r \\
\text { genes }\end{array}$} \\
\hline & & & $\begin{array}{l}\text { Field-1- } \\
2016\end{array}$ & $\begin{array}{l}\text { Field-1- } \\
2017\end{array}$ & $\begin{array}{l}\text { Field-1- } \\
2018\end{array}$ & $\begin{array}{l}\text { Field-2- } \\
2016\end{array}$ & $\begin{array}{l}\text { Field-2- } \\
2017\end{array}$ & \\
\hline Baganskaya-93 & & $\|$ & $4 / 805$ & $4 / 905$ & $4 / 50 S$ & $4 / 10 S$ & $4 / 50 S$ & $\operatorname{Lr} 17 a, \operatorname{Lr} 20$ \\
\hline Sirena & \multirow{9}{*}{$\begin{array}{l}\text { Krasnoyarskii krai / Krasnoyarskii } \\
\text { NIISKH }\end{array}$} & V & 2/15MR & 2/10MR & 3/40MS & $2 / 5 \mathrm{MR}$ & 2/15MR & Lr3a \\
\hline Krasa-2 & & III & $4 / 605$ & $4 / 605$ & $4 / 805$ & $4 / 70 \mathrm{~S}$ & $4 / 805$ & Lr3a, Lr10 \\
\hline Krasnoyarskaya-90 & & I & $4 / 805$ & $4 / 805$ & $4 / 70 \mathrm{~S}$ & $4 / 805$ & $4 / 905$ & Lr3a, Lr20 \\
\hline Vesnyanka-8 & & III & $4 / 905$ & $4 / 905$ & $4 / 70 S$ & $4 / 70 \mathrm{~S}$ & $4 / 90 \mathrm{~S}$ & Lr3a, Lr10, Lr20 \\
\hline Albidum-73 & & V & $4 / 605$ & $4 / 70 S$ & $4 / 70 S$ & $4 / 60 S$ & $4 / 805$ & Lr3a, Lr20 \\
\hline Rybinskaya-127 & & $\|$ & $4 / 605$ & $4 / 905$ & $4 / 805$ & $4 / 70 \mathrm{~S}$ & $4 / 905$ & Lr1 \\
\hline Kazachka & & V & $4 / 805$ & $4 / 905$ & $4 / 805$ & $4 / 605$ & $4 / 70 S$ & Lr3a \\
\hline Angarida & & III & $4 / 70 S$ & $4 / 805$ & $4 / 70 S$ & $4 / 605$ & $4 / 605$ & Lr3a \\
\hline Mana-2 & & I & $4 / 60 S$ & $4 / 805$ & $4 / 70 \mathrm{~S}$ & $4 / 60 S$ & $4 / 70 S$ & Lr3a \\
\hline Tuleevskaya & \multirow{10}{*}{$\begin{array}{l}\text { Kemerovskaya Oblast / Kemerovskii } \\
\text { NIISKH }\end{array}$} & V & 2/15MR & $4 / 705$ & $4 / 805$ & $4 / 10 S$ & $4 / 10 S$ & $\operatorname{Lrg}$ \\
\hline Izida & & V & $4 / 805$ & $4 / 905$ & $4 / 905$ & $4 / 70 S$ & $4 / 905$ & Lr3a, Lr16 \\
\hline Mariya & & I & $4 / 605$ & $4 / 805$ & $4 / 70 S$ & $4 / 15 S$ & $4 / 305$ & Lr3a, Lr10, Lr17a \\
\hline AN-34 & & V & 3/20MS & 3/20MS & $3 / 40 \mathrm{MS}$ & $3 / 5 \mathrm{MS}$ & 3/20MS & $\begin{array}{l}\operatorname{Lr} 1, \operatorname{Lr} 9, \operatorname{Lr} 10, \operatorname{Lr} 17 a \\
\operatorname{Lr} 20\end{array}$ \\
\hline Mariinka & & I & $4 / 605$ & $4 / 50 \mathrm{~S}$ & $3 / 60 \mathrm{~S}$ & $4 / 15 S$ & $4 / 305$ & Lr10, Lr16, Lr20 \\
\hline Salimovka & & III & $4 / 60 \mathrm{~S}$ & $4 / 805$ & $4 / 80 \mathrm{~S}$ & $4 / 60 S$ & $4 / 605$ & Lr3a, Lr10, Lr16 \\
\hline Kiiskaya & & V & $2 / 25 \mathrm{MR}$ & 3/30MS & 3/40MS & 3/30MS & 3/30MS & $\operatorname{Lr} 1, \operatorname{Lr} 3 a, \operatorname{Lr} 9$ \\
\hline Nostalgiya & & V & $4 / 605$ & $4 / 805$ & $4 / 80 S$ & $4 / 40 S$ & $4 / 605$ & Lr3a, Lr10 \\
\hline Aleshina & & $\|$ & $4 / 60 S$ & $4 / 905$ & $4 / 70 S$ & $4 / 15 S$ & $4 / 40 S$ & Lr3a, Lr10 \\
\hline Darnitsa & & III & $4 / 70 S$ & $4 / 905$ & $4 / 70 S$ & $4 / 30 S$ & $4 / 40 S$ & Lr3a, Lr10 \\
\hline Serebrina & \multirow{18}{*}{$\begin{array}{l}\text { Tyumenskaya Oblast / NIISKH } \\
\text { Severnogo Zauralya }\end{array}$} & $\|$ & 3/70MS & $4 / 70 S$ & $4 / 50 \mathrm{~S}$ & 3/60MS & $4 / 605$ & $L r 3 a, L r 20$ \\
\hline Rechka & & I & $4 / 605$ & $4 / 805$ & $4 / 70 S$ & $4 / 305$ & $4 / 50 S$ & $\operatorname{Lr}, \operatorname{Lr} 3 a, \operatorname{Lr} 7 \mathrm{Ta}$ \\
\hline Latona & & IV & $4 / 80 \mathrm{~S}$ & $4 / 805$ & $4 / 70 \mathrm{~S}$ & $4 / 20 S$ & $4 / 40 S$ & $L r 3 a, L r 17 a$ \\
\hline Provintsiya & & III & $4 / 805$ & $4 / 905$ & $4 / 70 S$ & $4 / 305$ & $4 / 50 \mathrm{~S}$ & Lr1, Lr3a, Lr10 \\
\hline Bel & & III & $4 / 70 \mathrm{~S}$ & $4 / 70 S$ & $4 / 70 \mathrm{~S}$ & $4 / 40 S$ & $4 / 50 \mathrm{~S}$ & Lr1, Lr3a, Lr10, Lr16 \\
\hline Ustya & & III & $4 / 605$ & $4 / 705$ & $4 / 50 S$ & $4 / 15 S$ & $4 / 305$ & Lr3a, Lr10 \\
\hline Chernyava-13 & & V & $4 / 705$ & $4 / 80 S$ & $4 / 70 S$ & $4 / 605$ & $4 / 60 S$ & LrI, Lr3a, Lr10 \\
\hline Zlatozara & & IV & $4 / 605$ & $4 / 805$ & $4 / 70 S$ & $4 / 20 S$ & $4 / 40 S$ & $L r 1, L r 3 a$ \\
\hline Tyumenskaya-99 & & III & $4 / 70 S$ & $4 / 805$ & $4 / 70 \mathrm{~S}$ & $4 / 30 S$ & $4 / 50 S$ & $\operatorname{Lr} 10, \operatorname{Lr} 16$ \\
\hline Ikar & & $\|$ & 2/10MR & $4 / 805$ & $4 / 605$ & $4 / 10 S$ & $4 / 305$ & Lr3a, Lr17a \\
\hline Skent-1 & & IV & $4 / 70 S$ & $4 / 905$ & $4 / 70 \mathrm{~S}$ & $4 / 70 S$ & $4 / 70 S$ & Lr3a, Lr20 \\
\hline Ilinskaya & & IV & $4 / 805$ & $4 / 805$ & $4 / 50 S$ & $4 / 605$ & $4 / 605$ & Lr3a, Lr10 \\
\hline Turinskaya & & I & $3 / 20 \mathrm{MS}$ & $4 / 40 S$ & 3/50MS & 3/10MS & $3 / 20 M S$ & Lr3a, Lr10, Lr17a \\
\hline Surenta-1 & & $\|$ & $4 / 905$ & $4 / 905$ & $4 / 60 S$ & $4 / 50 \mathrm{~S}$ & $4 / 50 S$ & Lr3a, LrI7a \\
\hline Surenta-4 & & IV & $4 / 605$ & $4 / 805$ & $4 / 50 \mathrm{~S}$ & $4 / 20 S$ & $4 / 405$ & Lr1, Lr20 \\
\hline Surenta-5 & & IV & $4 / 80 \mathrm{~S}$ & $4 / 905$ & $4 / 70 \mathrm{~S}$ & $4 / 70 \mathrm{~S}$ & $4 / 805$ & Lr3a \\
\hline Surenta-6 & & I & $4 / 80 \mathrm{~S}$ & $4 / 90 S$ & $4 / 605$ & $4 / 305$ & $4 / 40 S$ & Lr3a \\
\hline Surenta-7 & & I & $4 / 605$ & $4 / 905$ & $4 / 70 \mathrm{~S}$ & $4 / 605$ & $4 / 805$ & Lr3a, Lr10 \\
\hline Dias-2 & \multirow[t]{4}{*}{ Omskaya Oblast / Sibirskii NIISKH } & III & $4 / 70 \mathrm{~S}$ & $4 / 905$ & $4 / 70 S$ & $4 / 15 S$ & $4 / 50 \mathrm{~S}$ & Lr3a, Lr10 \\
\hline Irtyshanka-10 & & IV & $4 / 70 \mathrm{~S}$ & $4 / 80 \mathrm{~S}$ & $4 / 70 \mathrm{~S}$ & $4 / 70 \mathrm{~S}$ & $4 / 70 \mathrm{~S}$ & Lr1 \\
\hline Katyusha & & IV & $4 / 805$ & $4 / 905$ & 3/60MS & $4 / 405$ & 3/40MS & Lr3a, Lr34 \\
\hline Tarskaya-6 & & IV & $4 / 70 \mathrm{~S}$ & $4 / 805$ & $4 / 70 S$ & $4 / 70 S$ & $4 / 90 S$ & $\operatorname{Lr} 3 a, \operatorname{Lr} 10$ \\
\hline
\end{tabular}


Table 1 List of spring wheat varieties, their origin, leaf rust severity and postulated Lr resistance genes (Continued)

\begin{tabular}{|c|c|c|c|c|c|c|c|c|}
\hline \multirow[t]{2}{*}{ Variety } & \multirow[t]{2}{*}{ Region/Originator } & \multirow[t]{2}{*}{ Cluster $^{\mathrm{a}}$} & \multicolumn{5}{|c|}{ Infection type/severity ${ }^{\mathrm{b}}$} & \multirow{2}{*}{$\begin{array}{l}\text { Postulated } L r \\
\text { genes }\end{array}$} \\
\hline & & & $\begin{array}{l}\text { Field-1- } \\
2016\end{array}$ & $\begin{array}{l}\text { Field-1- } \\
2017\end{array}$ & $\begin{array}{l}\text { Field-1- } \\
2018\end{array}$ & $\begin{array}{l}\text { Field-2- } \\
2016\end{array}$ & $\begin{array}{l}\text { Field-2- } \\
2017\end{array}$ & \\
\hline Sonata & & V & 2/30MR & $4 / 20 S$ & 2/15MR & $0 / R$ & $0 / R$ & Lr1, Lr3a \\
\hline Strada-Sibiri & & I & $4 / 805$ & $4 / 905$ & $4 / 905$ & $4 / 70 S$ & $4 / 80 S$ & Lr20, Lr34 \\
\hline Otrada-Sibiri & & I & 2/10MR & $0 / R$ & 2/10MR & $0 / R$ & $0 / R$ & $\begin{array}{l}\text { Lr3a, Lr10, Lr17a, } \\
\text { Lr34 }\end{array}$ \\
\hline Tertsiya & & I & 2/10MR & 2/10MR & $1 / 5 \mathrm{MR}$ & $0 / R$ & $0 / R$ & Lr10 \\
\hline Priirtyshskaya-86 & & III & $4 / 10 S$ & $4 / 30 S$ & $3 / 40 \mathrm{MS}$ & $4 / 10 S$ & $4 / 30 S$ & Lr3a, Lr10 \\
\hline Rosinka-2 & & 1 & $4 / 80 \mathrm{~S}$ & $4 / 905$ & $4 / 70 S$ & $4 / 40 S$ & $4 / 50 S$ & Lr3a, Lr10, Lr17a \\
\hline Omskaya-20 & & III & $3 / 15 \mathrm{MS}$ & 2/20MR & 2/30MR & 3/30MS & 3/30MS & Lr1, Lr3a, Lr20, Lr26 \\
\hline Omskaya-23 & & I & 2/10MR & 3/50MS & 2/40MR & 2/10MR & 2/20MR & Lr3a, Lr10, Lr20 \\
\hline Omskaya-24 & & I & $4 / 70 S$ & $4 / 80 S$ & $4 / 60 S$ & $4 / 30 S$ & $4 / 50 \mathrm{~S}$ & Lr3a, Lr10, Lr20 \\
\hline Omskaya-26 & & III & $4 / 70 S$ & $4 / 805$ & $4 / 60 S$ & $4 / 30 S$ & $4 / 50 S$ & Lr3a, Lr10 \\
\hline Omskaya-28 & & IV & $4 / 70 S$ & $4 / 805$ & $4 / 70 S$ & $4 / 30 S$ & $4 / 50 S$ & $L r 17 a$ \\
\hline Omskaya-29 & & 1 & 3/20MS & 3/30MS & 3/50MS & 3/10MS & 3/30MS & $\begin{array}{l}\text { Lr1, Lr3a, Lr10, Lr26, } \\
\text { Lr34 }\end{array}$ \\
\hline Omskaya-31 & & IV & $4 / 70 \mathrm{~S}$ & $4 / 805$ & $4 / 70 S$ & $4 / 40 S$ & $4 / 50 S$ & Lr3a, Lr17a \\
\hline Omskaya-32 & & I & $4 / 60 S$ & $4 / 805$ & 3/60MS & $4 / 10 S$ & $4 / 30 S$ & Lr1, Lr3a \\
\hline Omskaya-33 & & IV & $4 / 60 \mathrm{~S}$ & $4 / 805$ & $4 / 605$ & $4 / 605$ & $4 / 70 \mathrm{~S}$ & $\operatorname{Lr} 1, \operatorname{Lr} 17 a$ \\
\hline Omskaya-34 & & IV & $3 / 40 \mathrm{MS}$ & 3/40MS & 3/40MS & $3 / 20 \mathrm{MS}$ & 3/20MS & $\begin{array}{l}\text { Lr1, Lr3a, Lr10, } \\
\text { Lr17a }\end{array}$ \\
\hline Omskaya-36 & & IV & $4 / 905$ & $4 / 905$ & $4 / 70 S$ & $4 / 70 \mathrm{~S}$ & $4 / 70 \mathrm{~S}$ & Lr1, Lr3a, Lr16 \\
\hline Skala & Irkutskaya oblast / Tulunskaya GSS & III & $4 / 905$ & $4 / 805$ & $4 / 70 \mathrm{~S}$ & $4 / 70 S$ & $4 / 70 \mathrm{~S}$ & Lr10 \\
\hline Tulun-15 & & III & $4 / 605$ & $4 / 70 S$ & $4 / 70 S$ & $4 / 70 S$ & $4 / 70 S$ & Lr10 \\
\hline
\end{tabular}

a Genetic clustering is presented according to the results of the STRUCTURE program

${ }^{b}$ Infection type was scored according to [27]. Severity ratings were scored as: $R$ Resistant, MR Moderate resistant, MS Moderate susceptible, $S$ susceptible; numeric character means $\%$ of leaf coverage by uredinia

seasons (Table 1). The severity rating of the remaining varieties varied depending on both the year of testing and the experimental fields. ANOVA performed on the results of a three-year evaluation of the susceptibility of cultivars to the pathogen indicated significant differences $(p<0.001)$ between genotypes, environments and the experimental fields (Table 2).

Despite the same type of response to the pathogen, varieties cultivated under Field-2 conditions had a lower degree of leaf coverage with urediniospores compared to Field-1 (Table 1). Thus, in half of the samples, the degree of infection in Field-1 varied from 10 to $40 \%$, while

Table 2 Analysis of variance of leaf rust resistance in spring wheat varieties

\begin{tabular}{lllll}
\hline & DF & SS & MS & F value \\
\hline Variety & 99 & 270,454 & 2732 & $16.62^{* * *}$ \\
Environments & 4 & 48,143 & 12,036 & $73.23^{* * *}$ \\
Field-1vsField-2 & 1 & 35,123 & 35,123 & $179.45^{* * *}$ \\
Error & 396 & 65,077 & 164 & \\
\hline *** Significant at $p<0.0001$ & & &
\end{tabular}

*** Significant at $p<0.0001$ in Field-2 the same level of susceptibility was observed only in 21-33 varieties depending on the year of field evaluation (Fig. 1).

The number of highly and moderately-resistant varieties did not exceed $10 \%$ in different environmental conditions, with three varieties (Tulaikovskaya-zolotistaya, Tulaikovskaya-10, Samsar), created in Samarskii NIISKH, characterized as immune in all years of investigation. Based on the results of phytopathological assessments, varieties Tulaikovskaya-1, Volgouralskaya, Obskaya-14, Sonata, Sirena, Otrada-Sibiri, and Tertsiya were also noted, which showed low ITs in the conditions of Field-2.

\section{Population structure and association mapping}

The population structure of wheat varieties was analyzed using 5950 SNP markers. The largest number of markers was used for genome B (2615 markers) compared to genomes A (2060) and D (736). According to the data obtained using the programs STRUCTURE and STRUCT URE HARVESTER, an assumption was made that the optimal number of subclusters is 5. Analysis of the 


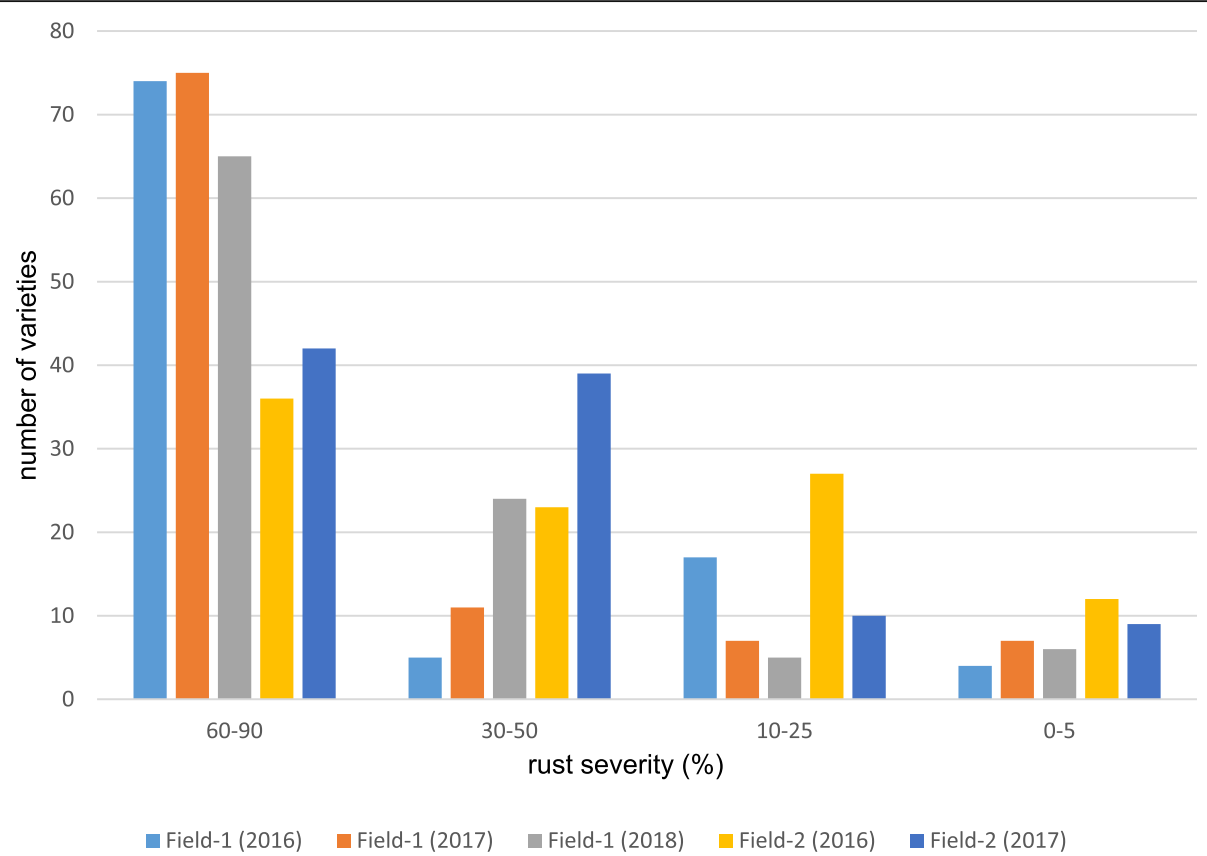

Fig. 1 Diagram of distribution of spring wheat varieties by susceptibility to leaf rust on the experimental trials Field-1 and Field-2 in 2016-2018

composition of the subclusters did not reveal a clear separation of cultivars according to their origin from different breeding companies (Table 1). Thus, varieties of the selection of SiBNIIRS (Novosibirskaya oblast) are presented in all five subclusters. Varieties created in the breeding companies of the Altai, Krasnoyarsk, Kemerovo, Tyumen and Omsk regions are part of four out of the five subclusters. Varieties developed in Samarskii NIISKH, with the exception of the breeding line Kuibyshevskaya-2, are grouped in two subclusters (I and IV).

In addition, principal component analysis (PCA) performed with the help of the PAST program [28] was used to clarify genetic relationships. The results of PCA also did not reveal a genetically significant distribution of wheat collection into clear subpopulations (Additional file 2: Figure S1). The first two main components included 14.2 and $8.3 \%$ of genetic variation, respectively. The lack of a clear differentiation of cultivars can be explained by the fact that, since the 1970s of last century, varieties created in NIISH Yugo-Vostoka (Saratov) have become widespread. These varieties have now been widely involved in breeding in the Siberian and Ural regions [29].

Genotyping of wheat varieties showed no amplification for 118 SNP markers out of 13,007. After filtering, the number of markers used for associative mapping was 9406 (Additional file 3: Table S2). The number of markers mapped to different chromosomes of A, B or D genomes differed significantly, the smallest number was observed for chromosomes of the 4th homoeological group. Two variants of the MLM model were used for GWAS, one of which (MLM-1) included population structure and kinship $(Q+K)$, the other - MLM-2- only kinship $(K)$. The quantile-quantile plots $(\mathrm{QQ})$, illustrating the correspondence between the observed and expected $p$-values for the two models, is presented in Additional file 4: Figure S2.

Based on the results of GWAS, 20 SNP markers located on eight chromosomes $(6 \mathrm{D}, 6 \mathrm{~A}, 6 \mathrm{~B}, 5 \mathrm{~A}, 1 \mathrm{~B}, 2 \mathrm{~A}$, $2 \mathrm{~B}$ and $7 \mathrm{~A}$ ) were revealed, which showed reliable marker-trait association (Table 3, Fig. 2). The results presented in Table 3 indicate that MLM-1 and MLM-2 detected the same set of SNPs; the differences were only in the degree of reliability of MTAs, which were higher for the MLM-2 model.

Five significant markers with a high contribution to the trait manifestation in the range from $-2,86$ to $-3,90$ in three wheat varieties (Tulaikovskaya-zolotistaya, Tulaikovskaya-10, and Samsar) were revealed at chromosome 6D, among which four SNPs were null alleles (no amplification of the fragments in the genome of the varieties). Previously, we have shown for varieties Tulaikovskaya-5, Tulaikovskaya-10, and Tulaikovskaya100 that the wheat chromosome $6 \mathrm{D}$ was replaced by the chromosome $6 \mathrm{Ai}=2$ from wheatgrass Thinopyrum intermedium [31]. Additionally, it was found that this wheatgrass chromosome carries at least one leaf rust resistance gene, $L r 6 A i=2$, for which STS markers (Additional file 5: Table S3) were developed. Analysis of amplification of SNP markers, mapped to chromosome 6D, in varieties Tulaikovskaya-zolotistaya, Tulaikovskaya 10 , 
Table 3 List and chromosomal localization of SNPs significantly associated with resistance to leaf rust

\begin{tabular}{|c|c|c|c|c|c|c|c|}
\hline Marker & SNP ID & Chromosome $^{a}$ & Position, $\mathrm{CM}^{*}$ & Allele $^{\mathrm{b}}$ & $P$ value MLM-1/MLM-2 & $R^{2 c}$ & $\overline{\text { Effect }}$ \\
\hline BS00063175_51 & IWB9015 & $6 \mathrm{DL}$ & 84.54 & $\mathrm{G} / \mathrm{A}$ & 2.02E-05/4.81E-09 & $0.22-0.27$ & -3.4 \\
\hline BobWhite_c13435_700 & IWB505 & $6 \mathrm{DL}$ & 149.85 & & 5.69E-08/9.48E-09 & $0.32-0.48$ & -3.90 \\
\hline BS00070856_51 & IWB10505 & $6 \mathrm{DL}$ & 153.07 & & 2.83E-05/8.3E-06 & $0.18-0.29$ & -2.86 \\
\hline GENE-4153_101 & IWB33802 & $6 \mathrm{DL}$ & 82.14 & & 7.37E-06/1.87E-06 & $0.20-0.27$ & -2.96 \\
\hline D_GB5Y7FA02G6KBX_382 & IWB18070 & $6 \mathrm{DL}$ & 83.75 & & $9.71 \mathrm{E}-06 / 1.2 \mathrm{E}-06$ & $0.22-0.27$ & -3.18 \\
\hline IAAV8633 & IWB35508 & $6 \mathrm{AS}$ & 3.43 & $\mathrm{~T} / \mathrm{C}$ & 1.80E-04/1.58E-07 & $0.11-0.20$ & -1.64 \\
\hline BS00037006_51 & IWB8079 & $6 \mathrm{AL}$ & 83.73 & $\mathrm{C} / \mathrm{A}$ & 2.58E-05/2.31E-08 & $0.09-0.13$ & -1.52 \\
\hline wsnp_Ex_rep_c69526_68472787 & IWA5615 & $5 \mathrm{AS}$ & 35.94 & $\mathrm{~T} / \mathrm{G}$ & $6.05 E-06 / 1.70 \mathrm{E}-13$ & $0.24-0.27$ & -3.16 \\
\hline GENE-3321_201 & IWB33331 & $5 A S$ & 36.72 & $\mathrm{~A} / \mathrm{C}$ & $6.05 \mathrm{E}-06 / 1.07 \mathrm{E}-13$ & $0.24-0.27$ & -3.16 \\
\hline Kukri_c8835_112 & IWB48151 & $5 \mathrm{AS}$ & 36.58 & $\mathrm{~T} / \mathrm{C}$ & 6.05E-06/1.07E-13 & $0.20-0.27$ & -3.12 \\
\hline BS00094095_51 & IWB11853 & $5 \mathrm{AS}$ & 36.87 & $\mathrm{~T} / \mathrm{C}$ & 6.05E-06/1.45E-09 & $0.22-0.29$ & -2.48 \\
\hline tplb0023b14_704 & IWB74145 & $1 \mathrm{BL}$ & 70.07 & $\mathbf{T} / \mathrm{G}$ & 2.15E-06/1.45E-09 & $0.17-0.26$ & -0.62 \\
\hline wsnp_Ra_c8484_14372815 & IWA8082 & $1 \mathrm{BL}$ & 69.76 & $\mathrm{C} / \mathrm{T}$ & 2.15E-06/1.45E-09 & $0.17-0.26$ & -0.62 \\
\hline TA004947-0758 & IWB65906 & $1 \mathrm{BL}$ & 66.07 & $\mathrm{C} / \mathrm{A}$ & 9.28E-06/2.54E-06 & $0.16-0.22$ & -0.64 \\
\hline BobWhite_c1456_615 & IWB669 & $1 \mathrm{BL}$ & 64.89 & $\mathrm{C} / \mathrm{A}$ & 1.06E-05/2.04E-06 & $0.15-0.19$ & -0.58 \\
\hline RAC875_c8849_134 & IWB60932 & 1BS & 62.84 & $\mathrm{C} / \mathrm{T}$ & 3.87E-05/9.78E-06 & $0.07-0.12$ & -0.31 \\
\hline wsnp_Ku_rep_c71900_71624324 & IWA7504 & 1BS & - & $\mathbf{A} / \mathrm{G}$ & 1.15E-04/5.09E-06 & $0.08-0.12$ & -0.16 \\
\hline IAAV2452 & IWB34561 & 1BS & 62.63 & $\mathrm{~T} / \mathrm{C}$ & 3.49E-04/8.40E-06 & $0.04-0.09$ & -0.30 \\
\hline Excalibur_c18514_238 & IWB23156 & $2 \mathrm{AL}$ & 144.13 & $\mathbf{G} / \mathbf{T}$ & 3.31E-05/5.68E-07 & $0.15-0.20$ & -0.87 \\
\hline Excalibur_c48404_59 & IWB26954 & $2 B L$ & 161.41 & $\mathrm{~T} / \mathrm{C}$ & 3.79E-05/8.25E-06 & $0.10-0.13$ & -0.54 \\
\hline
\end{tabular}

a localization and marker position on the chromosome are indicated according to the consensus maps of wheat (T. aestivum L.) presented in [30] and Triticeae Toolbox database (https://triticeaetoolbox.org/)

${ }^{b}$ favorable alleles are highlighted in bold;

${ }^{c} R^{2}$ indicates phenotypic variation explained by the significant locus in different environments

and Samsar showed that $20 \%$ of the markers of the long arm are null alleles, which suggests the presence of chromosome substitution/translocation from $T h$. intermedium.

Two markers (IAAV8633 and BS00037006_51) that showed significant MTAs were located at the long and short arms of wheat chromosome 6A (Table 3). Favorable alleles of these markers with high reliability were detected only in varieties Tulaikovskaya-zolotistaya, Tulaikovskaya-10, and Samsar. Four informative SNPs with an effect on the phenotypic manifestation of the trait from -2.48 to -3.16 were identified at the $5 \mathrm{AS}$ chromosome. Favorable alleles were detected in the genomes of four varieties, Tulaikovskaya-zolotistaya, Tulaikovskaya-10, Samsar, and Volgouralskaya.

At the chromosome $1 \mathrm{~B}$, seven reliable MTAs were detected. Four of these SNPs were located at the long arm of the chromosome according to consensus maps. Favorable alleles of $1 \mathrm{BL}$ were found in the group of varieties including Sonata, Otrada-Sibiri, Tertsiya, Omskaya-23 developed in Sibirskii NIISKH, in Tulaikovskaya-1, Obskaya-14, and Sirena varieties created in the breeding centers Samarskii NIISKH, SibNIIRS and Krasnoyarskii NIISKH respectively. The favorable alleles for three
SNPs located at the chromosome 1BS with minor effects from -0.16 to -0.31 were detected in varieties Kinelskaya-60, Omskaya-20 and Omskaya-29.

Significant association with resistance to leaf rust was shown for two markers mapped on chromosomes $2 \mathrm{AL}$ and 2BL. It should be noted that the favorable allele of the marker Excalibur_c18514_238 located at chromosome 2AL was revealed in the genome of Tulaikovskayazolotistaya, Tulaikovskaya 10, and Volgouralskaya varieties, whereas the favorable allele of the Excalibur c48404_59 located at chromosome 2BL was found in Obskaya-14, Sonata, Tertsiya, Omskaya-23.

\section{Molecular marker analysis}

The results of genotyping of wheat varieties with primers designed for the genes $\operatorname{Lr} 1, \operatorname{Lr} 3 a, \operatorname{Lr} 9, \operatorname{Lr} 10$, Lr16, Lr17a, Lr20, Lr21, Lr24, Lr25, Lr26, Lr28, Lr29, $L r 34, L r 37$, and $L r 6 A i=2$ (Additional file 5: Table S3) are presented in Table 1. It transpired that most varieties contain genes $L r 1, L r 3 a, L r 10, L r 17 a$, and Lr2O that are not currently effective. According to the marker analysis, these genes are postulated in the genome of $25,75,48,24$ and 21 varieties, respectively. There was no amplification of PCR fragments 


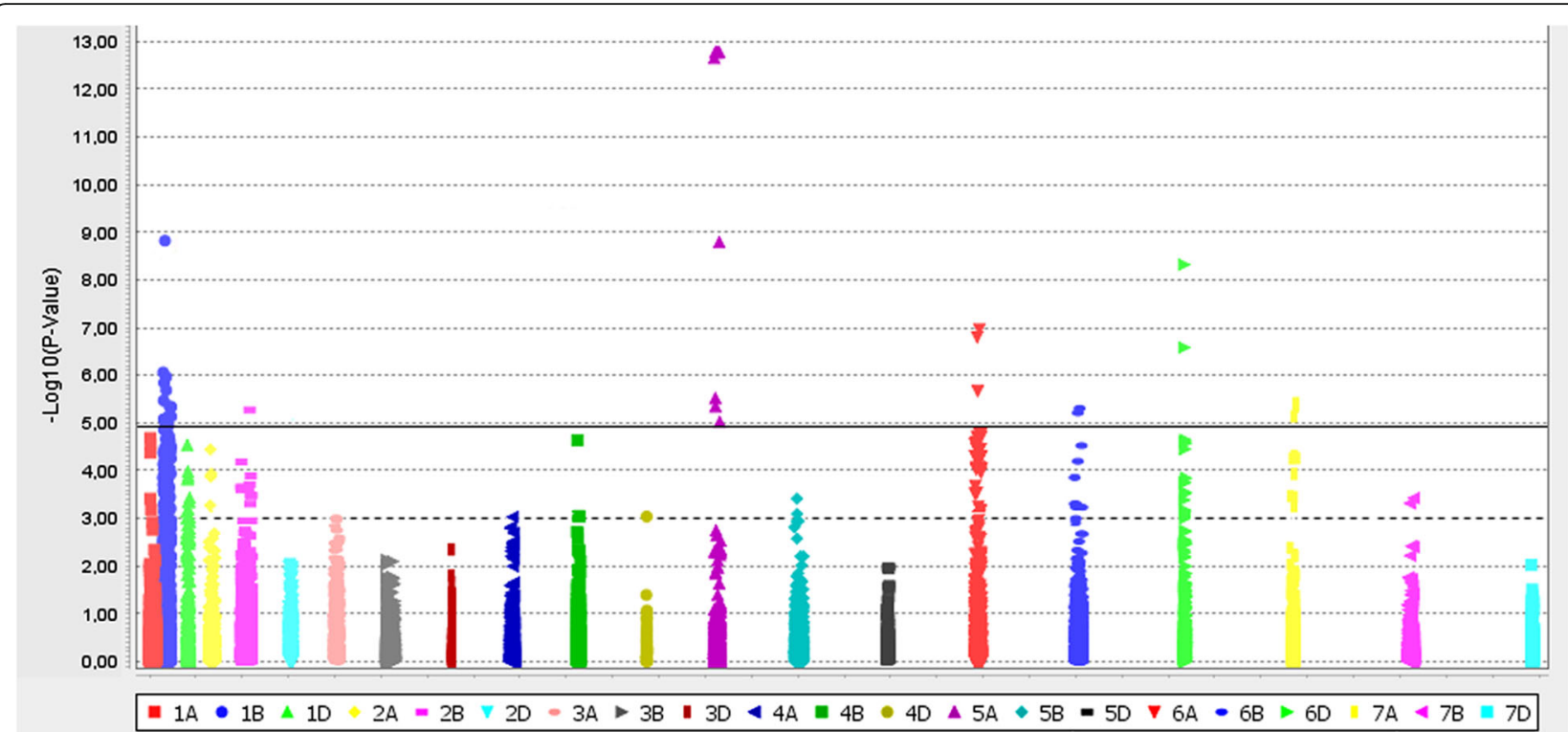

Fig. 2 Manhattan plot illustrating the distribution of SNP associated with leaf rust resistance of wheat varieties. Markers located above the horizontal solid line are reliable at Bonferroni corrected $p$-value threshold $\left(1.06 \times 10^{-5}\right)$. Dashed line indicate $p$-value of $1 \times 10^{-3}$

using primers specific to alien resistance genes $\operatorname{Lr} 24$, Lr25, Lr28, Lr29 and Lr37. Seven varieties (Altaiskiiprostor, Altaiskaya-99, Aleksandrina, Udacha, Tuleevskaya, AN-34, and Kiiskaya) revealed a fragment of length 1110 bp using primer J13, developed for the gene $\operatorname{Lr} 9$. According to the published data obtained on the basis of molecular screening, varieties Altaiskaya-99, Udacha, Tuleevskaya, Aleksandrina, Sonata, and Tertsiya are carriers of $\operatorname{Lr} 9$ [22, 23, 32]. However, no amplification of the fragment diagnostic to $\operatorname{Lr} 9$ was found in Sonata and Tertsiya varieties in our study.

The PrCEN-2 and $\omega$-sec-P1/P2 markers designed for the rye $1 \mathrm{RS}$ chromosome were used to identify the T1RS.1BL translocation containing the $L r 26$ gene (Additional file 5: Table S3). Diagnostic fragments were amplified with DNA of three varieties: Kinelskaya-60, Omskaya-20, and Omskaya-29. In eight varieties, adult plant resistance gene Lr34 was postulated based on the results obtained using the markers cssfr3 and csLV34 (Additional file 6: Figure S3). Identification of the $L r 6 A i=2$ gene from Th. intermedium was carried out using the STS marker $X i c g 6 A i=2$. PCR fragments indicating the presence of the wheatgrass genome are detected in the varieties Tulaikovskaya-zolotistaya, Tulaikovskaya-10, and Samsar (Additional file 6: Figure S4). In cv. Volgouralskaya, a $220 \mathrm{bp}$ fragment was synthesized using the $X w m c 221$ microsatellite marker, recommended for detecting the $\operatorname{Lr} 19$ gene. The fact that the Volgouralskaya variety is a carrier of $\operatorname{Lr} 19$ was shown using the $X w m c 221, \mathrm{~Gb}, \mathrm{SCS} 265$ and SCS253 markers in the investigations of other researchers [22, 23, 33].

\section{Discussion}

This paper presents the results of an analysis of the diversity of Russian spring wheat varieties on genetic loci determining resistance to the leaf rust pathogen. Presence of resistance loci in the genome was postulated based on the comparison of data obtained using GWAS, amplification of PCR markers recommended for the detection of $L r$ genes, and phytopathological evaluation in different environments.

\section{Comparison of significant QTLs with known leaf rust resistance genes}

The results of GWAS suggested the presence of the locus $L r 6 A i=2$ from Th. intermedium in the genomes of Tulaikovskaya-zolotistaya, Tulaikovskaya 10, and Samsar varieties (Table 1). PCR analysis using STS primers also confirmed the existence of $L r 6 A i=2$ in these cultivars (Additional file 6: Figure S4). Phytopathological evaluation suggests that the varieties demonstrated a type of reaction nearing full immunity in different environments, indicating a high efficiency of the gene $L r 6 A i=2$.

In the Tulaikovskaya-zolotistaya, Tulaikovskaya-10, and Samsar varieties, reliable MTAs were detected for markers mapped to the 5AS, 6DL, 6AS and 6AL chromosomes (Table 3). Associations with SNPs of chromosome 5AS were also established for the Volgouralskaya variety. At present, the minor locus QLr.pbi-5AS is mapped on the short arm of chromosome $5 \mathrm{~A}$ of bread wheat [34]. In addition, association mapping revealed a genomic region on chromosome $5 \mathrm{~A}$, which determines the resistance of durum wheat varieties to leaf rust [35]. Based on the location of QTLs, as well as their origin, 
the locus on 5AS found in this study cannot be attributed to any of the known genes. This suggests the presence of a previously unknown QTL for resistance to leaf rust in the genomes of Tulaikovskaya-zolotistaya, Tulaikovskaya-10, Samsar, and Volgouralskaya varieties.

Genes Lr56, Lr62 and Lr64 inherited from wheat relatives Ae. sharonensis, Ae. neglecta, and T. dicoccoides were transferred to chromosome 6A [4, 36, 37]. Associations of markers mapped to chromosome $6 \mathrm{~A}$ may be explained by the presence of fragments of chromosome 6Ai from Th. intermedium both in chromosomes of the 6th homoeological group and in the other chromosomes of Tulaikovskaya-zolotistaya, Tulaikovskaya-10, and Samsar varieties. Such cases are described in the literature. For instance, for the gene $\operatorname{Lr} 38$, derived from $T h$. intermedium, several translocation lines with localization of the wheatgrass genome fragment $7 \mathrm{Ai}=2 \mathrm{~L}$ in $3 \mathrm{D}, 6 \mathrm{D}$, 1D, 2A chromosomes are known [38, 39]. For the $\operatorname{Lr} 9$ gene inherited from Ae. umbellulata common wheat lines were obtained containing translocations in chromosomes 4BS, 2DL, 7BS [40]. However, to confirm this assumption additional cytological analysis is required.

Earlier, based on phytopathological tests confirmed by molecular analysis with Gb and SCS265 markers developed for the $\operatorname{Lr} 19$ gene, it was suggested that cultivar Samsar is a carrier of this gene [21, 23, 41]. However, the results of PCR with primers for the gene $L r 6 A i=2$, as well as the type of reaction to the pathogen, indicate that the resistance of the Samsar variety is determined by the gene $L r 6 A i=2$ (Additional file 6: Figure S4). Moreover, the use of the primer wmc221 did not reveal amplification of the fragment diagnostic for $\operatorname{Lr} 19$.

Three varieties (Kinelskaya-60, Omskaya-20, and Omskaya-29) are carriers of the gene Lr26, introduced as part of the wheat-rye translocation. This is evidenced by both GWAS results which indicated three reliable MTAs in chromosome 1BS, and molecular screening by markers PrCEN-2 and $\omega$-sec-P1/P2. Pedigree analysis of these varieties shows that the cv. Caucasus - the source of Lr26 gene (http://wheatpedigree.net/) took part in their creation. Additionally, it was shown that SNP marker TG0025, developed for 1RS/1BL translocation by TraitGenetics $\mathrm{GmbH}$ (personal communication), is detected only in these three varieties $(p<1.04 \mathrm{E}-05)$. For the Kinelskaya-60, Omskaya-20, and Omskaya-29 - carriers of the $\operatorname{Lr} 26$ gene, the type of reaction is moderately susceptible (IT $=3 / 15-50 \mathrm{MS}$ ), indicating a decrease in the efficacy of the gene (Table 1).

The presence of the $\operatorname{Lr} 9$ gene was postulated in Altaiskii-prostor, Altaiskaya-99, Aleksandrina, Udacha, Tuleevskaya, AN-34, and Kiiskaya varieties by PCR results with the J13 marker. However, GWAS did not identify reliable MTAs $(p<0.001)$ specific for chromosomal localization of the gene $\operatorname{Lr} 9$ inherited from $A e$. umbellulata as part of the T6BS.6BL-6 U\#1 L. Phytopathological screening indicates that all varieties showed susceptible response to the pathogen, indicating a loss of effectiveness of this gene to the native population of leaf rust.

Analysis of the GWAS results revealed that seven varieties (Sonata, Otrada-Sibiri, Tertsiya, Omskaya-23, Obskaya-14, Tulaikovskaya-1, and Sirena) are combined into a group characterized by a set of associated SNPs mapped to the long arm of chromosome 1B. According to phytopathological testing presented by Sing et al. [21], the gene $L r 23$ inherited from T. durum was postulated in the genome of Tulaikovskaya-1. Taking into account the loss of efficacy of the $L r 23$ and $L r 9$ genes to P. triticina populations in Western Siberia [3, 32, 42], low susceptibility to leaf rust of Sonata, Otrada-Sibiri, Tertsiya, Omskaya-23, Obskaya-14, Tulaikovskaya-1, and Sirena may indicate the presence of an unknown locus in chromosome $1 \mathrm{~B}$, which provides a resistance response.

\section{Effectiveness of leaf rust resistance genes in Western Siberia}

The obtained results indicate the absence of effective resistance genes to Puccinia triticina in most Russian spring wheat varieties. Only 15 varieties out of 100 are characterized by high or moderate resistance to the pathogen, of which three varieties - carrying the gene $L r 6 A i=2$ demonstrated an "immune" reaction type. The Lr19 gene has retained its effectiveness, as evidenced by both the infection type of the cv. Volgouralskaya and the data obtained earlier using the RL6040 isogenic Thatcher line [3]. It can be assumed that the West Siberian population of $P$. triticina does not contain races that are virulent to Lr19; however, this requires additional study of the virulence of the local population. Nevertheless, it is clear that the phytopathological situation in the region is fundamentally different from other regions of Russia, where the protective effect of the Lr19 gene is overcome. Currently, virulence to Lr19 is registered in many Russian regions where varieties with this gene are cultivated [42-44].

Until recently, when creating varieties of spring wheat adapted for Western Siberia, hybridization schemes included mainly sources of genes $\operatorname{Lr} 9$ and $\operatorname{Lr} 19$ that have long maintained their effectiveness in many regions of the world [45-47]. There is evidence, based mainly on the data of hybridological analysis, that a number of varieties of local selection contain the gene $\operatorname{LrTr}=\operatorname{Lr} 9$ [48, 49]. However, intensive use of the same type of material with the $\operatorname{Lr} 9$ gene led to the appearance of isolates virulent to this gene, and, accordingly, its loss of efficacy. This is confirmed by the results presented in this study, which indicate that the varieties carrying $\operatorname{Lr} 9$ are characterized by a susceptible response to the pathogen. 
A significant decrease in the effectiveness of the juvenile gene $L r 26$ and the adult plant resistance gene $L r 34$ and the appearance of virulent races was recorded in the Tyumen, Omsk and Novosibirsk regions, which are part of the Ural and West Siberian regions [42, 50, 51]. In our study, marker analysis led us to postulate the presence of Lr34 in eight wheat varieties (Kuibyshevskaya-2, Altaiskaya-92, Altaiskaya-325, Ustya, Katyusha, StradaSibiri, Otrada-Sibiri, and Omskaya-29). However, for six of them, excluding Otrada-Sibiri and Omskaya-29, which contain genes $\operatorname{Lr} 26$ and an unidentified gene in chromosome $1 \mathrm{BL}$, high susceptibility to the pathogen was noted (IT = 4/15-90S; Table 1 ).

Monitoring of virulence of the West Siberian population conducted in 2007-2017, showed a high susceptibility for wheat samples containing leaf rust resistance genes $L r 1, L r 2 a, L r 2 b, L r 2 c, L r 2 d, L r 3 a, L r 3 b g, L r 3 k a$, Lr9, Lr10, Lr11, Lr14a, Lr15, Lr16, Lr17a, Lr20, Lr22a, Lr23, Lr26, Lr30, Lr32, Lr33, Lr34, Lr44 [3, 32]. It is important to note that there was a difference in infectious backgrounds (subpopulations of $P$. triticina) from Field1 and Field-2, which consisted not so much in the composition of virulence genes, but in the degree of aggressiveness of the infection in the Field-1 microclimate. Immunity to the field population of the leaf rust was preserved by carriers of the $\operatorname{Lr} 19, \operatorname{Lr} 24, \operatorname{Lr} 28, \operatorname{Lr} 35, \operatorname{Lr} 45$, $L r 47, \operatorname{Lr} 50, \operatorname{Lr} 52(\mathrm{Lr} W)$ genes. Our results suggest that the local population either does not contain the corresponding virulence genes or the resistance genes listed are able to effectively protect genotypes in the region.

\section{Conclusions}

A comprehensive assessment carried out using genomewide association study, molecular marker analysis and phytopathological evaluation, suggests that most of the studied Russian spring wheat varieties do not contain genes that provide effective resistance to $P$. triticina. The results indicate that the protective effects of the genes Lr9 and Lr26 have been overcome, whereas genes $L r 6 A i=2$ and $L r 19$ retain their effectiveness. Based on the localization and origin of known leaf rust loci, QTLs on chromosomes $5 \mathrm{AS}$ and $1 \mathrm{BL}$ cannot be attributed to any of the known resistance genes. The SNPs, which showed reliable MTAs in this study, can be used for development of new markers for identification of leaf rust resistance loci.

\section{Methods}

\section{Plant material and field experiments}

The plant material included 100 varieties and breeding lines of spring bread wheat, created by eight breeding companies of the Russian Federation; the list includes both old-fashioned varieties and varieties of modern selection. The list of varieties is presented in Table 1 and
Additional file 7: Table S4, more detailed pedigree information can be found in the GRIS Internet resources (Genetic Resources Information System for Wheat and Triticale, http://wheatpedigree.net) and in the database of the bioresource collections of the IC\&G SB RAS (http://ckp.icgen.ru/plants/fond). Seeds were obtained from the National Genebank of Russian Federation (VIR, Federal Research Center N.I. Vavilov All-Russian Institute of Plant Genetic Resources, St. Petersburg; http:// db.vir.nw.ru/virdb/maindb), were maintained and multiplied in The Federal Research Center Institute of Cytology and Genetics SB RAS (IC\&G SB RAS, Novosibirsk).

Wheat varieties were grown in 2016-2017 on two experimental fields of IC\&G, located in the Novosibirsk region and further designated as Field-1 $\left(54.9191^{\circ} \mathrm{N}\right.$, $\left.82.9903^{\circ} \mathrm{E}\right)$ and Field-2 $\left(54.8475^{\circ} \mathrm{N}, 83.1095^{\circ} \mathrm{E}\right)$. In 2018, phytopathological screening for leaf rust susceptibility was conducted only on Field-1. Experimental plots are affected differently by wind. The open area of Field-1 provides the best assessment of the natural infection. The area of Field-2 is surrounded by forest and is not exposed to airborne spores of pathogen well. However here there is always good humidity, due to the duration and intensity of precipitation, stable dew and the period of leaf moistening, which makes it possible to evaluate the disease even in years unfavorable for the development of rust.

Varieties were sown in a randomized block design with two replications at each of two experimental fields. The seeds were planted in rows of $1 \mathrm{~m}$ long, the distance between rows was $25 \mathrm{~cm}$ and the distance between plants within a row was $5 \mathrm{~cm}$. Field response to uncontrolled, natural infection of leaf rust was estimated twice per season at booting and early milk stages. Type of reaction and severity ratings were determined using the 0-4point scale of Mains and Jackson [27] and a modified Cobb scale [52].

\section{Genotyping and DNA marker analysis}

Genomic DNA was isolated from 5 to 7-day-old seedlings as described in [53]. For SNP genotyping, DNA was purified on micro columns from the "Bio-Silica" company according to the manufacturer's instructions. Genotyping was carried out with the help of the Illumina Infinium $15 \mathrm{~K}$ array of TraitGenetics GmbH (www.traitgenetics.de), which included 13,007 SNP markers mapped in the wheat genome [30].

For postulation of the presence of $L r$ resistance genes, wheat genotypes were analyzed using PCR markers developed for genes $L r 1, L r 3 a, L r 9, L r 10, L r 16, L r 17 a$, Lr20, Lr21, Lr24, Lr25, Lr26, Lr28, Lr29, Lr34, Lr37, and $L r 6 A i=2$. Thatcher near isogenic lines and wheat cultivars containing $L r$ genes were used as controls. PCR was 
performed according to published protocols in a $20 \mu \mathrm{l}$ reaction mixture containing $50 \mathrm{ng}$ of DNA. The list of used markers, primer sequences and references are presented in Additional file 5: Table S3. PCR products were separated in a $1.5 \%$ agarose gel, stained with ethidium bromide and visualized on the Gel Doc digital gel documentation system (Applied Biosystems).

\section{Data analysis}

Analysis of variance (ANOVA) of the data on leaf rust resistance in different environments was performed using the program STATISTICA v. 10 (www.statsoft.ru). The population structure (Q-matrix) was estimated using a Bayesian algorithm implemented in the program STRUCTURE 2.3.4 [54]. Q-matrix was calculated based on the results of genotyping with 5950 SNP markers. The number of suspected subclusters ranged from 1 to 10. The simulation was performed using the admixture model; the number of runs was five with a burn-in length of 20,000 and Markov chain iterations of 50,000. The most likely number of clusters is calculated from Delta $K(\Delta K)$ statistics [55] using the web-based program Structure Harvester [56]. Principal component analysis (PCA) implemented in the PAST v. 3.15 program was used to group the accessions based on genetic similarity [28]. Kinship $(K)$ matrix was calculated using the program TASSEL V. 5.2.24 [57]. A complete set of SNP markers was used to calculate the K-matrix, with the exception of markers that showed missing data for all analyzed samples.

Marker-trait associations (MTAs) were determined on the basis of mixed linear model (MLM) with kinship matrix $(K)$ and population structure $(Q)$ as covariate using the program TASSEL v. 5.2.24. SNP markers with MAF (minor allele frequency) less than $5 \%$ and missing data > $20 \%$ were not included in the analysis. After filtering, the number of markers was 9406 . Two criteria were used to identify reliable MTAs: 1) Bonferroni multiple correction with $\alpha=0.1$, which corresponded to marker-wise probability $\left.p<1.06 \times 10^{-} 5 ; 2\right)$ a false discovery rate (FDR) of $p<0.001$ as the threshold to identify markers associated with resistance, taking into account only markers that showed associations in at least two environments. The proposed genetic location of QTLs associated with resistance was determined using consensus maps of hexaploid wheat chromosomes presented in Wang et al. [30].

\section{Supplementary information}

Supplementary information accompanies this paper at https://doi.org/10. 1186/s12870-020-02333-3.

Additional file 1: Table S1. Meteorological conditions for the growing seasons of 2016, 2017 and 2018 (Novosibirskaya oblast, weather station $\left.54.54^{\circ} \mathrm{N}, 82.57^{\circ} \mathrm{E}\right)$.
Additional file 2: Figure S1. A scatter plot of PCA of the spring wheat varieties obtained on the base of SNP genotyping.

Additional file 3: Table S2. Number of SNP markers with localizations in the $A, B$ and $D$ genomes used for genotyping wheat varieties.

Additional file 4: Figure S2. Quantile - quantile plots demonstrating the ratios of expected to observed $\log 10$ (P) values.

Additional file 5: Table S3. List of primers used for postulation of $L r$ genes in spring wheat varieties.

Additional file 6: Figure S3. PCR profile of primer cssfr3 for Lr34 gene with DNA wheat varieties Kuibishevskaya-2, Altaiskaya-92, Altaiskaya-325, Ustya, Katyusha, Otrada-Sibiri and isogenic Thatcher line RL6058. Figure S4. Electrophoretic image of PCR fragments obtained by amplification of DNA of wheat varieties with primer $X_{i c g} 6 \mathrm{Ai}=2$ developed for the gene LrGAi=2.

Additional file 7: Table S4. Wheat accessions used in the genomewide association study (GWAS) for leaf rust severities.

\section{Abbreviations}

ANOVA: Analysis of variance;" GWAS: Genome-wide association study;i IT: Infection type; LD: Linkage disequilibrium; Lr: Leaf rust;" MAF: Minor allele frequency; MAS: Marker-assisted selection;; MLM: Mixed linear model;" MTA: Marker-trait association;; QQ: Quantile-quantile; QTL: Quantitative trait loci; SNP: Single nucleotide polymorphism; SR: Severity ratings

\section{Acknowledgements}

The authors thank Likhenko I.E. (SibNIIRS-branch of the IC\&G SB RAS) for the collection of common wheat varieties used in this study.

\section{Availability of data and material}

Authors can confirm that all relevant data are included in the article and/or its supplementary information files.

\section{About this supplement}

This article has been published as part of BMC Plant Biology Volume 20 Supplement 1, 2020: Selected articles from the 5th International Scientific Conference "Plant genetics, genomics, bioinformatics, and biotechnology" (PlantGen2019). The full contents of the supplement are available online at https://bmcplantbiol.biomedcentral.com/articles/supplements/volume-20supplement-1.

\section{Authors' contributions}

INL and EAS carried out the experimental design; INL and ESS performed field trials. INL performed statistical analysis and GWAS and prepared draft version of the manuscript. All authors have read and approved the final version of the manuscript for publication.

\section{Funding}

This work was supported by Russian Science Foundation, grant No. 16-1600011 (including the publication costs). Multiplication of seed material was carried out in Laboratory of artificial plant growth in the framework of the budget project 0324-2019-0039-C-01. EAS is grateful to Kurchatov Genomics Center of IC\&G for support in the part of $L r$ marker selection, agreement No. 075-15-2019-1662. The funders had no role in study design, data collection and analysis, decision to publish, or preparation of the manuscript.

Ethics approval and consent to participate

This study does not contain any research requiring ethical consent or approval.

\section{Consent for publication}

Not applicable.

\section{Competing interests}

The author declares no competing interest.

\section{Author details}

${ }^{1}$ The Federal Research Center Institute of Cytology and Genetics of Siberian Branch of the Russian Academy of Sciences, Novosibirsk 630090, Russia. 
${ }^{2}$ Kurchatov Genomics Center Institute of Cytology and Genetics SB RAS, Novosibirsk 630090, Russia.

\section{Received: 12 September 2019 Accepted: 6 March 2020} Published online: 14 October 2020

\section{References}

1. Mikhailova LA, Gultyaeva El, Walter U, Kophanke D. An attempt to review Puccinia recondita f. sp. triciti populations in Western and Eastern Europe together with the Asian part of Russia. J Russ Phytopathol Soc. 2002;3:1-6.

2. Kiseleva MI, Kolomiets TM, Pakholkova EV, Zhemchuzhina NS, Lubich W. Differentiation of winter wheat (Triticum aestivum L.) cultivars for resistance to harmful fungal pathogens. Agricultural Biology. 2016;51:299-309.

3. Skolotneva ES, Leonova IN, Bukatich EY, Boiko NI, Piskarev W, Salina EA. Effectiveness of leaf rust resistance genes against Puccinia triticina populations in Western Siberia during 2008-2017. J Plant Dis Protection. 2018;125:549-55.

4. McIntosh RA, Dubcovsky J, Rogers WJ, Morris C. Catalogue of gene symbols for wheat. 2013, supplements 2014-2017. http://shigen. nig.ac.jp/wheat/ komugi/genes/)

5. Kolmer JA. Postulation of leaf rust resistance genes in selected soft red winter wheats. Crop Sci. 2003;43:1266-74.

6. Singh D, Park RF, Mclntosh RA. Postulation of leaf (brown) rust resistance genes in 70 wheat cultivars grown in the United Kingdom. Euphytica. 2001; 120:205-18.

7. Li J, Shi L, Wang X, Zhang N, Wei X, Zhang N, Wei X, Zhang L, Yang W, Liu D. Leaf rust resistance of 35 wheat cultivars (lines). J Plant Pathol Microbiol. 2018;9:429.

8. McCallum BD, Hiebert C, Huerta-Espino J. Cloutier S. In: Sharma I, editor. Disease resistance in wheat. Wallingford: CAB International; 2012. p. 33-62.

9. Goutam U, Kukreja S, Yadav R, Salaria N, Thakur K, Goyal AK. Recent trends and perspectives of molecular markers against fungal diseases in wheat Front Microbiol. 2015;6:861.

10. Chełkowski J, Golka L, Stepień Ł. Application of STS markers for leaf rust resistance genes in near-isogenic lines of spring wheat CV. 'Thatcher'. J Appl Genet. 2003:44:323-38

11. Serfling A, Krämer I, Lind V, Schliephake E, Ordon F. Diagnostic value of molecular markers for $L r$ genes and characterization of leaf rust resistance of German winter wheat cultivars with regard to the stability of vertical resistance. Eur J Plant Pathol. 2011:130:559.

12. Pinto da Silva GB, Zanella CM, Martinelli JA, Chaves MS, Hiebert CW, McCallum BD, Boyd LA. Quantitative trait loci conferring leaf rust resistance in hexaploid wheat. Phytopathology. 2018;108:1344-54

13. Kumar S, Archak S, Tyagi RK, Kumar J, Vikas VK, Jacob SR, et al. Evaluation of 19,460 wheat accessions conserved in the Indian National Genebank to identify new sources of resistance to rust and spot blotch diseases. PLoS One. 2016:11(12):e0167702.

14. Chen H, Semagn K, labal M, Moakhar NP, Haile T, N'Diaye A, Yang R-C, Hucl P, Pozniak C, Spaner D. Genome-wide association mapping of genomic regions associated with phenotypic traits in Canadian western spring wheat. Mol Breed. 2017:37:141.

15. Kankwatsa P, Singh D, Thomson PC, Babiker EM, Bonman JM, Newcomb M, Park RF. Characterization and genome-wide-association mapping of resistance to leaf rust, stem rust and stripe rust in a geographically diverse collection of spring wheat landraces. Mol Breed. 2017;37:113.

16. Mwadzingeni $L$, Shimelis $H$, Rees DJG, Tsilo TJ. Genome-wide association analysis of agronomic traits in wheat under drought- stressed and nonstressed conditions. PLoS One. 2017;12(2):e0171692.

17. Prins R, Dreisigacker S, Pretorius Z, van Schalkwyk H, Wessels E, Smit C, Bender $C$, Singh D, Boyd LA. Stem rust resistance in a geographically diverse collection of spring wheat lines collected from across Africa. Front Plant Sci. 2016;7:973.

18. Muleta KT, Rouse MN, Rynearson S, Chen X, Buta BG, Pumphrey MO Characterization of molecular diversity and genome-wide mapping of loci associated with resistance to stripe rust and stem rust in Ethiopian bread wheat accessions. BMC Plant Biol. 2017;17:134.

19. Gao L, Turner MK, Chao S, Kolmer J, Anderson JA. Genome wide association study of seedling and adult plant leaf rust resistance in elite spring wheat breeding lines. PLoS One. 2016;11(2):e0148671.
20. Turner MK, Kolmer JA, Pumphrey MO, Bulli P, Chao S, Anderson JA. Association mapping of leaf rust resistance loci in a spring wheat core collection. Theor Appl Genet. 2017;130:345-61.

21. Singh RP, Morgunov A, Huerta-Espino J. Genes conferring low seedling reaction to Mexican pathotypes of Puccinia recondita f. sp. tritici, and adultplant responses of recent wheat cultivars from the former USSR. Euphytica. 1995;81:225-34

22. Morgounov A, Ablova I, Babayants O, Babayants L, Bespalova L, Khudokormov Z, Litvinenko N, Shamanin V, Syukov V. Genetic protection of wheat from rusts and development of resistant varieties in Russia and Ukraine. Euphytica. 2011;179:297-311.

23. Gultyaeva El. Genetic diversity of Russian common wheat varieties for leaf rust resistance. Russian Agricult Sci. 2012;38:125-8.

24. Shishkin NV, Derova TG, Gultyaeva El, Shaydayuk EL. Identification of the genes resistant to brown rust in winter soft wheat varieties with the use of conventional and modern research methods. Grain Econ Russia. 2018;5:63-7.

25. Davoyan ER, Bespalova LA, Davoyan RO, Zubanova YS, Mikov DS, Filobok VA, Khudokormova JN. Use of molecular markers in wheat breeding for resistance to leaf rust at the Lukyanenko research Institute of Agriculture. Rus J Genet Appl Res. 2015;5:227-32.

26. Sibikeev SN, Druzhin AE, Badaeva ED, Shishkina AA, Dragovich AY, et al. Comparative analysis of Agropyron intermedium (host) Beauv $6 \mathrm{Ag}^{\mathrm{i}}$ and $6 \mathrm{Ag}^{\mathrm{i}} 2$ chromosomes in bread wheat cultivars and lines with wheat-wheatgrass substitutions. Russ J Genet. 2017:53:314-24.

27. Mains EB, Jackson HS. Physiological specialization in the leaf rust of wheat, Puccinia triticina Eriks. Phytopathology. 1926;16:89-120.

28. Hammer $\varnothing$, Harper DAT, Ryan PD. PAST: paleontological statistics software package for education and data analysis. Palaeontol Electron. 2001:4(1):1-9.

29. Anosov SI, Sovetov W, Likhenko IE, Ageeva EV, Likhenko NI, Shraiber PP. Development of mid-ripening varieties of spring common wheat. Siberian Herald Agricult Sci. 2015;5:20-5.

30. Wang S, Wong D, Forrest K, Allen A, Chao S, Huang BE, et al. Characterization of polyploid wheat genomic diversity using a high-density 90,000 single nucleotide polymorphism array. Plant Biotechnol J. 2014;12: 787-96.

31. Salina EA, Adonina IG, Badaeva ED, Kroupin PY, Stasyuk AI, Leonova IN, et al. A Thinopyrum intermedium chromosome in bread wheat cultivars as a source of genes conferring resistance to fungal diseases. Euphytica. 2015; 204:91-101.

32. Sochalova LP, Likhenko IE. Evaluation of resistance to brown rust of $L r$-lines and varieties of wheat, isogenic in genes under conditions of Novosibirsk regions. Achiev Sci Technol. 2016;30:46-50.

33. Skolotneva ES, Leonova IN, Bukatich EY, Salina EA. Methodical approaches to identification of effective wheat genes providing broad-spectrum resistance against fungal diseases. Vavilov J Genet Breed. 2017;21(7):862-9.

34. Singh D, Simmonds J, Park RFH, Bariana S, Snape JW. Inheritance and QTL mapping of leaf rust resistance in the European winter wheat cultivar 'Beaver'. Euphytica. 2009;169:253.

35. Maccaferri M, Sanguineti MC, Mantovani P, Demontis A, Massi A, Ammar K, Kolmer JA, Czembor JH, Ezrati S, Tuberosa R. Association mapping of leaf rust response in durum wheat. Mol Breed. 2010;26:189-228.

36. Marais GF, McCallum B, Marais AS. Leaf rust and stripe rust resistance genes derived from Triticum sharonensis. Euphytica. 2006;149:373-80.

37. Marais F, Marais A, McCallum B, Pretorius Z. Transfer of leaf rust and stripe rust resistance genes Lr62 and Yr42 from Aegilops neglecta Req. ex Bertol. to common wheat. Crop Sci. 2009;49:871-9.

38. Friebe B, Mukai Y, Gill BS, Cauderon Y. C-banding and in-situ hybridization analysis of Agropyron intermedium, a partial wheat $x$ Ag. intermedium amphiploid, and six derived chromosome addition lines. Theor Appl Genet. 1992:84:899-905.

39. Friebe B, Jiang J, Gill BS, Dyck PL. Radiation-induced nonhomoeologus wheat-Agropyron intermedium chromosomal translocations conferring resistance to leaf rust. Theor Appl Genet. 1993;86:141-9.

40. Friebe B, Jiang J, Raupp WJ, McIntosh RA, Gill BS. Characterization of wheatalien translocation conferring resistance to diseases and pests: current status. Euphytica. 1996;91:59-87.

41. Martynov SP, Dobrotvorskaya TV, Krupnov VA. Genealogical analysis of the use of two wheatgrass (Agropyron) species in common wheat (Triticum aestivum L.) breeding for disease resistance. Rus J Genet. 2016;52:154-63. 
42. Tyunin VA, Shreyder ER, Gultyaeva El, Shaidayuk EL. Characteristics of virulence of Puccinia triticina populations and the potential of the Lr24, Lr25, LrSp genes for spring common wheat breeding in the southern Ural. Vavilov J Genet Breed. 2017:21:524-9.

43. Sibikeev SN, Krupnov VA, Voronina SA, Elesin VA. First report of leaf rust pathotypes virulent to highly effective $L r$-genes transferred from Agropyron species to bread wheat. Plant Breed. 1996;115:276-8.

44. Gultyaeva El, Kovalenko NM, Shamanin VP, Tyunin VA, Shreyder ER, Shaydayuk EL, Morgunov Al. Population structure of leaf pathogens of common spring wheat in the west Asian regions of Russia and North Kazakhstan in 2017. Vavilov J Genet Breed. 2018;22(3):363-9.

45. McIntosh RA, Wellings CR, Park RF. Wheat rust: an atlas of resistance genes. Austalia: Melbourne; 1995.

46. Kolmer JA. Genetics of resistance to wheat leaf rust. Annu Rev Phytopathol. 1996;34:435-55

47. Vida G, Cséplõ M, Gulyás G, Karsai I, Kissi T, et al. Effectiveness of major resistance genes and identification of new sources for disease resistance in wheat. Acta Agronomica Hungarica. 2011;59:241-8.

48. Likhenko IE, Stepochkin PI, Khristov YA, Sochalova LP, Artyomova GV, Zyryanova AF, Ponomarenko VI. Sources of resistance against unfavorable biotic and abiotic factors of environment in Siberian gene pool of wheat, rye and triticale. Proc Appl Bot Genet Breed. 2009;166:168-73.

49. Likhenko IE, Sochalova LP. Studying resistance of wheat to leaf pathogens under conditions of Western Siberia. Siberian Herald Agricult Sci. 2011;1: $18-25$.

50. Gultyaeva E, Dmitriev A, Kosman E. Regional diversity of Russian populations of Puccinia triticina in 2007. Can J Plant Pathol. 2012;34:213-23.

51. Sochalova LP, Piskarev W. Resistance of varieties of spring soft wheat to agents of infections under conditions of changing climate of Western Siberia. Achiev Sci Technol. 2017;31:21-5.

52. Peterson RF, Campbell AB, Hannah AE. A diagrammatic scale for estimating rust intensity of leaves and stems of cereals. Can J Res Sec C. 1948;26: 496-500.

53. Kiseleva AA, Shcherban AB, Leonova IN, Frenkel Z, Salina EA. Identification of new heading date determinants in wheat $5 B$ chromosome. BMC Plant Biol. 2016;16(Suppl 1):8.

54. Pritchard J, Stephens M, Donnelly P. Inference of population structure using multilocus genotype data. Genetics. 2000;155:945-59.

55. Evanno G, Regnaut S, Goudet J. Detecting the number of clusters of individuals using the software STRUCTURE: a simulation study. Mol Ecol. 2005;14:2611-20.

56. Earl DA, VonHoldt BM. STRUCTURE HARVESTER: a website and program for visualizing STRUCTURE output and implementing the Evanno method. Conserv Genet Resour. 2012;4:359-61.

57. Bradbury PJ, Zhang Z, Kroon DE, Casstevens TM, Ramdoss Y, Buckler ES. TASSEL: software for association mapping of complex traits in diverse samples. Bioinformatics. 2007;23:2633-5.

\section{Publisher's Note}

Springer Nature remains neutral with regard to jurisdictional claims in published maps and institutional affiliations.

Ready to submit your research? Choose BMC and benefit from:

- fast, convenient online submission

- thorough peer review by experienced researchers in your field

- rapid publication on acceptance

- support for research data, including large and complex data types

- gold Open Access which fosters wider collaboration and increased citations

- maximum visibility for your research: over $100 \mathrm{M}$ website views per year

At BMC, research is always in progress.

Learn more biomedcentral.com/submissions 